\title{
Etnomatematika Pada Budaya Masyarakat Dayak Perbatasan Indonesia-Malaysia
}

\author{
Agung Hartoyo \\ Pendidikan Matematika, FKIP Universitas Tanjungpura
}

\begin{abstract}
Abstrak
Penelitian ini bertujuan untuk mengungkap etnomatematika yang dipraktekkan oleh masyarakat Dayak di perbatasan Indonesia-Malaysia wilayah Kalimantan Barat dalam menjalani kehidupan sehari-hari. penelitian kualitatif. Penelitian ini merupakan studi eksplorasi dengan pendekatan interpretivisme dan metode interpretative understanding. Objek penelitian ini adalah aktivitasaktivitas masyarakat Dayak dalam menjalani kehidupannya sehari-hari. Warga masyarakat Dayak perbatasan Kalimantan Barat yang mengetahui, memahami, serta terampil dalam memproduksi karya budaya dan mengetahui seluk beluk adat istiadat masyarakat setempat dipilih sebagai sumber data penelitian. Hasil penelitian menunjukkan bahwa etnomatematika digunakan oleh masya-rakat ketika mereka melakukan aktivitas melakukan berbagai upacara adat, menenum kain, menganyam tikar. Meskipun masyarakat tidak paham matematika, namun mereka menerapkan konsep matematika (geometri) yang rumit diterapkan pada motif-motif anyamannya.
\end{abstract}

Kata kunci : etnomatematika, budaya masyarakat dayak

\section{Pendahuluan}

Dalam pergaulan masyarakat modern, diakui bahwa matematika merupakan salah satu mata pelajaran yang dipandang penting di sekolah. Tetapi, mengajar matematika dengan baik merupakan pekerjaan yang sulit. Pemberlakuan kurikulum 2006 mendorong reformasi dalam pendidikan matematika, konsepkonsep matematika perlu dibelajarkan dengan mempertimbangkan aspekaspek lokal yang berkembang dalam masyarakat di sekitar lingkungan siswa.

Salah satu tujuan belajar matematika adalah membentuk skemata baru dalam struktur kognitif dengan mempertimbangkan skemata anak sehingga terjadi asimilasi. Mengaitkan antara pengetahuan awal siswa dengan pemahaman konteks di lingkungannya dapat dipertimbangkan dalam pembelajaran. Kecenderungan yang berlangsung dalam pembelajaran matematika mengawali dengan eksplorasi pengetahuan informal yang diperoleh siswa dari lingkungan sekitar tempat tinggalnya. Langkah awal yang perlu dilakukan, dan menjadi fokus dalam penelitian ini adalah melakukan eksplorasi investigasi unsur-unsur budaya masyarakat yang memuat konsepkonsep matematika. Hasil eksplorasi tersebut dijadikan dasar dalam pengembangan bahan ajar matematika 
berbasis unsur lokal yang memperhatikan lingkungan social budaya dan kearifan lokal masyarakat.

Shirley (2001), berpandangan bahwa sekarang ini bidang etnomathematika, yaitu matematika yang timbul dan berkembang dalam masyarakat dan sesuai dengan kebudayaan setempat, merupakan pusat proses pembelajaran dan metode pengajaran. Hal ini membuka potensi pedagogis yang mempertimbangkan pengetahuan para siswa yang diperoleh dari belajar di luar kelas. Matematika itu pada hakekatnya tumbuh dari keterampilan atau aktivitas lingkungan budaya (Bishop, 1994), sehingga matematika seseorang dipengaruhi oleh latar belakang budayanya (Pinxten, 1994). Matematika yang berkembang dalam lingkungan masyarakat, oleh Bishop disebut etnomatematik. "Ethnomathematics in the elementary classroom is where the teacher and the students value cultures, and cultures are linked to curriculum" (Barta \& Shockey, 2006 : 79). Etnomatematika merupakan representasi kompleks dan dinamis yang menggambarkan pengaruh kultural penggunaan matematika dalam aplikasinya.

Dalam era perkembangan seperti sekarang, masyarakat adat di perbatasan tengah mengalami terpaan pola hidup modernitas dan diskriminasi dalam berbagai aspek. Masyarakat kesulitan membendung arus modernisasi, melindungi dan mempertahankan nilai kebudayaannya. Masyarakat Dayak tengah mengalami proses transformasi budaya. Masuknya kebudayaan dan nilai-nilai luar atau asing ke dalam masyarakat tradisional mengakibatkan terjadinya perubahan sosial budaya (Widjono, 1998).
Dewasa ini masyarakat adat sedang dalam proses perubahan, kini mereka menjadi sosok yang terbuka terhadap realitas kehidupan modernitas masa kini.

Menumbuhkan pemahaman lintas budaya mutlak diperlukan dalam masya-rakat multietnik dan multikultur yang sedang mengalami perubahan ke arah kehidupan modernitas. Saluran-saluran yang dapat dipakai antara lain pendidikan dalam keluarga, sosialisasi dan internalisasi nilai-nilai masyarakat melalui pergaulan sosial maupun media, serta melalui pendidikan berbasis kultural. Pendidikan berbasis kultural ini merupakan pendidikan yang memfasilitasi siswa memahami materi pembelajaran tanpa adanya kendala perbedaan latar belakang kultural (Bryant, 1996) dan pemahaman keberagaman dan penghargaan perbedaan-perbedaan, serta bersikap dan bertindak dalam situasi multietnik-multikultur (Matsumoto, 1996).

Ada lima dimensi yang terkandung dalam pendidikan berbasis kultural, yaitu pengintegrasian isi, konstruksi pengetahuan, pengurangan prasangka, keadilan pedagogik, dan empowering kultur sekolah (Banks, 1994). Salah satu bentuknya adalah pembelajaran yang membuat siswa terikat dengan lingkungan budayanya dengan pengajaran ethnoscience. Pada pengajaran ini membahas keterkaitan topik pembelajaran (ilmu pengetahuan kealaman) dengan etnik atau budaya manusia (Lara-Alecio, 2001), termasuk diantaranya adalah ethnomathematics. Bentuk lain adalah manajemen kelas yang baik yang memungkinkan terciptanya kerjasama antara siswa dengan berbagai latar 
belakang kultural (Brown, 1995) dan meningkatkan hubungan antar siswa yang berbeda budaya(Santrock, 1999).

Selama ini matematika kerap dipandang sebagai mata pelajaran yang sulit oleh siswa. Hal itu dikarenakan pembelajaran matematika di sekolah terlalu bersifat formal dan sering berbeda dengan yang ditemukan sehari-hari (Hilbert dan Carpenter, 1991). Para guru sering lupa bahwa para siswa telah memiliki pengetahuan matematika informal yang diperoleh dari kehidupan masyarakat atau di lingkungannya. Pengetahuan informal ini perlu diketahui oleh para guru sebelum melaksanakan pembelajaran matematika di kelas. Oleh karena itu, sangat penting bila konsep-konsep matematika yang terdapat dalam kebudayaan digali agar konsep tersebut dapat digunakan untuk membantu siswa dalam mempelajari matematika di sekolah.

\section{Metode Penelitian}

Matematika yang digunakan oleh masyarakat tersurat dan tersirat dalam berbagai unsur budaya. Untuk matematika yang tersurat mudah untuk diidentifikasi, dikenali dan diinventarisir, namun untuk matematika tersembunyi dan tersirat dalam unsur budaya cukup sulit untuk mengenali atau mengidentifikasi. Penggalian ide-ide matematika yang terkandung secara implisit dalam unsur-unsur budaya masyarakat, menurut psikologi tindakan dapat digolongkan sebagai tindakan sosial. Proses melakukan tindakan melibatkan interpretasi dan pemaknaan tanda atau simbol-simbol dan disertai dengan orientasi untuk mencari dan menemukan tindakan yang masuk akal atas situasi yang dihadapi (van Oers, 1996).

Uraian tersebut di atas menunjukkan bahwa penelitian ini cenderung berpijak pada paradigma penelitian sosial yang memandang bahwa penggalian aktivitas masyarakat didasarkan pada pemaknaan atas label-label pada suatu objek. Pemberian makna yang berbeda terhadap suatu label akan memberikan konsekuensi yang ber-beda pula pada hasil interpretasi. Sesuai dengan paradigma tersebut, maka variasi penggalian ide-ide matematika yang terkandung dalam unsur-unsur budaya menjadi konsep-konsep matematika perlu dicermati. Oleh karena itu, penelitian ini lebih menekankan pada upaya mencari pemahaman aktivitas masyarakat dalam pengem-bangan ide-ide matematika dari dunia real.

Untuk mencapai maksud tersebut, maka penelitian ini memerlukan pendekatan interpretivisme dengan metode interpretative understanding (Miles dan Huberman, 1994). Dengan demikian, jenis penelitian yang sesuai dengan kondisi tersebut di atas adalah penelitian kualitatif. Pada studi eksplorasi ini diinventarisir konsepkonsep matematika (etnomatematika) yang terkandung dalam budaya masyarakat atau digunakan dalam berbagai aktivitas kehidupan masyarakat Dayak. Yang menjadi sumber data adalah warga masyarakat Dayak perbatasan Kalimantan Barat yang mengetahui, memahami, serta terampil dalam memproduksi karya budaya, mengetahui seluk beluk adat istiadat masyarakat setempat, dan bersedia dengan suka rela memberikan informasi yang dimilikinya. 
Model pengumpulan dan analisis data pada penelitian ini dilakukan secara siklis yang meliputi aktivitasaktivitas : pengumpulan data, reduksi data, display data, dan penarikan

\section{Hasil dan Pembahasan}

Sebagaimana dikemukakan oleh Kutjaraningrat (2000), wujud kebudayaan merupakan suatu sistem dari suatu ide-ide dan konsep-konsep dari wujud kebudayaan sebagai suatu rangkaian tindakan dan aktivitas manusia yang berpola. Aktivitas manusia yang saling berinteraksi tidak lepas kesimpulan/verifikasi. Siklus analisis data diberhentikan ketika permasalahan penelitian sudah menemukan jawaban yang memadai.

dari berbagai penggunaan peralatan yang bersifat kongkret dan berupa benda-benda atau hal-hal yang dapat diraba, dilihat, dan difoto, seperti bangunan-bangunan megah seperti piramida, tembok cina, menhir, alatalat rumah tangga seperti kapak perunggu, gerabah.

Tabel 1: Sebutan Bilangan Dalam Budaya Dayak Kanayatn, Dayak Sekapat, dan Dayak Desa

\begin{tabular}{|c|c|c|c|c|}
\hline $\begin{array}{c}\text { Simbol } \\
\text { Bil. }\end{array}$ & $\begin{array}{l}\text { Sebutan bilangan oleh } \\
\text { suku Dayak Kanayatn }\end{array}$ & $\begin{array}{c}\text { Sebutan bilangan oleh } \\
\text { suku Dayak Sekapat }\end{array}$ & $\begin{array}{c}\text { Sebutan bilangan } \\
\text { oleh } \\
\text { suku Dayak Desa }\end{array}$ & $\begin{array}{c}\text { Sebutan } \\
\text { Hindu- } \\
\text { Arab }\end{array}$ \\
\hline 1 & Asa '/sabiti'/sete & Sutik & Suti' / sigi' / satu & Satu \\
\hline 2 & Duwa / duwabiti' / duaete' & Duwa/Duaitik & $\begin{array}{c}\text { Duwauti' / } \\
\text { duwaigi' / duwa }\end{array}$ & Dua \\
\hline 3 & Talu / talubiti' / taluete' & Tiga & $\begin{array}{l}\text { Tigauti' / tigaigi' / } \\
\text { tiga }\end{array}$ & Tiga \\
\hline 4 & $\begin{array}{l}\text { Ampat / ampatbiti' / } \\
\text { ampatete' }\end{array}$ & Ampat & $\begin{array}{c}\text { Empatuti' / } \\
\text { empatigi' / empat }\end{array}$ & Empat \\
\hline 5 & Lima / limabiti' / limaete' & Limak & $\begin{array}{c}\text { Limauti' / } \\
\text { limaigi' / lima'k }\end{array}$ & Lima \\
\hline 6 & $\begin{array}{l}\text { Anam / anambiti / } \\
\text { anamete' }\end{array}$ & Anam & $\begin{array}{c}\text { Enamutl'/ } \\
\text { enamigi' / enam }\end{array}$ & Enam \\
\hline 7 & Tujuh / tujuhbiti / tujuhete' & Tujoh & $\begin{array}{c}\text { Tujuhuti' / } \\
\text { tujuigi' / tujuh }\end{array}$ & Tujuh \\
\hline 8 & & & $\begin{array}{c}\text { Lapanuti' / } \\
\text { lapanigi' / lapan }\end{array}$ & Delapan \\
\hline 9 & & & $\begin{array}{c}\text { Milanuti' / } \\
\text { milanigi' / Milan }\end{array}$ & Sembilan \\
\hline 10 & & & $\begin{array}{c}\text { Puluhuti' / } \\
\text { puluigi' / puluh }\end{array}$ & Sepuluh \\
\hline
\end{tabular}

Menurut pemikiran Bishop (1988), aktivitas manusia yang bersentuhan dengan wujud kebudayaan pada wujud ketiga dan berkaitan dengan aktivitas manusia merupakan fenomena matematika yang terdiri dari enam kegiatan mendasar. Aktivitas- aktivitas tersebut selalu dapat ditemukan pada sejumlah kelompok budaya yaitu : menghitung membilang, penentuan lokasi, mengukur, mendesain, bermain dan menjelaskan. Hasil-hasil eksplorasi aktivitas masyarakat Dayak perbatasan 
yang memuat konsep matematika dapat dikemukakan seperti berikut :

\section{Membilang}

Membilang merupakan salah satu aktivitas yang sering dilakukan masyarakat, berkaitan dengan banyaknya sesuatu, jawaban dari pertanyaan berapa banyak ?". Bagi anak-anak pemula yang masih berada dalam tahap berpikir konkrit atau bagi komunitas masyarakat tradisionil, untuk membilang mereka memerlukan alat-alat bantu. Berbagai jenis alat bantu yang sering digunakan oleh masyarakat Dayak untuk membilang antara lain : jari tangan, tangan, batu, tongkat, dan tali (rotan dan akar). Penyebutan bilangan oleh masyarakat sering menggunakan istilah yang berbeda di antara satu sub suku dengan sub suku lainnya. Masyarakat Dayak Kanayatn, Dayak Sekapat, dan Dayak Desa menggunakan sebutan seperti terlihat pada Tabel 1.

Tabel 1 memperlihatkan bahwa penyebutan bilangan yang digunakan oleh ketiga sub suku di Kalimantan Barat mempunyai kemiripan antara yang satu dengan yang lainnya. Penyebutan bilangan sebagaimana digunakan masyarakat sub-suku Dayak Desa lebih kaya dari dua sub suku lainnya. Penggunaan bilangan tersebut oleh sub Suku Dayak Desa untuk menunjukkan jumlah tertentu dalam aktivitas mereka. Pada pembuatan kain tenun aktivitas membilang dengan sebutan pada kolom tiga Tabel 1 dilakukan ketika si penenun menghitung banyaknya bahan benang yang diperlukan untuk membuat kain tenun, banyaknya bahan benang disesuaikan dengan banyak kain ukuran kain yang ingin dihasilkannya. Dalam sekali menenun, biasanya mereka membuat kain tenunan sebanyak dua sampai empat helai sekaligus. Membilang juga dilakukan oleh penenun ketika membentuk motif pada kain.

\section{Mengukur dan pengukuran}

Pengukuran merupakan penentuan besaran, dimensi, atau kapasitas, biasanya terhadap suatu standar atau satuan pengukuran. Mengukur merupakan aktivitas yang biasa dilakukan dalam proses jual beli atau barter, rancang bangun, menentukan tinggi - panjang - keliling - luas - kedalaman, kecepatan dan sebagainya. Pengukuran yang dilakukan oleh masyarakat Dayak pada jaman dulu menggunakan alat-alat ukur yang tidak baku seperti penggunaan angota badan seperti tangan - depa jengkal atau menggunakan alat ukur berupa barang-barang yang tersedia atau buatan seperti tombak - galah untuk mengukur panjang, dan kaleng gantang untuk mengukur volume. Satuan pengukuran yaitu ukuran dari suatu besaran yang digunakan dalam pengukuran menyesuaikan dengan alat ukurnya, misalnya satuan depa, hasta, jengkal, kaki, kaleng, gantang dan sebagainya. Besaran waktu dapat mempunyai satuan detik, menit, koma, jam, hari dan sebagainya.

Beberapa sub-suku masyarakat Dayak menggunakan alat ukur yang bervariasi dalam melakukan pengukuran, antara lain : jari tangan, kaki, gantang (alat untuk menakar padi), dan sebagainya. Alat ukur yang digunakan masyarakat tersebut tidak standar karena tidak sama untuk semua orang. Pada pembuatan perisai kegiatan mengukur dilakukan ketika membuat rancang bangun perisai yaitu menggunakan jari tangan yang istilah 
ukurnya jangkal (jari tangan orang dewasa), sebagai alat ukur untuk menentukan jarak antara motif yang satu dengan yang lain digunakan jari tangan yang istilah ukurnya sajari, dan untuk ukuran yang lebih besar digunakan tangan yang istilah ukurnya dapa' yaitu satu rentangan tangan orang dewasa.

Aktivitas mengukur bagi masyarakat sub-suku Dayak dapat diamati ketika mereka melakukan pengukuran pada barang-barang produk anyamannya atau menen-tukan ukuran motif. Secara umum jarang ditemukan orang atau anggota masyarakat yang menyimpan alat ukur standar atau baku. Namun demikian aktivitas pengukuran tetap dilakukan oleh masyarakat setempat dengan menggunakan alat ukur terntentu dan dengan satuan sesuai dengan alat ukur yang digunakannya. Beberapa jenis alat ukur dan satuan ukuran yang digunakan oleh masyarakat perbatasan ini antara lain :

a. Lambar adalah alat ukur dengan menggunakan bilah bambu bahan anyaman. Ukuran satu lambar setara dengan lebar sebilah bambu dibelah empat yang sudah disisik halus.

b. Tunjuk adalah alat ukur dengan menggunakan jari telunjuk si penganyam. Ukuran satu tunjuk setara dengan lebar telunjuk si penganyam atau telunjuk orang dewasa.

c. Jengkal adalah alat ukur dengan menggunakan telapak tangan orang dewasa. Satu jengkal sama dengan jarak antara ujung ibu jari dan ujung jari tengah direntang secara penuh.

d. Genggam adalah alat ukur yang menggunakan genggaman tangan orang dewasa, dan satuan ukurannya disebut genggam. Ukuran satu genggam sama dengan satu kepalan tangan orang dewasa.

e. Kalik adalah alat ukur yang digunakan untuk menentukan besarnya keliling suatu barang, umumnya hasil kerajinan anyaman. Ukuran keliling tepi suatu Ragak, takin, ataupun Tanggui sebesar keliling kepala orang dewasa dikatakan satu kalik.

f. Seta adalah alat ukur masyarakat dengan menggunakan anggota badan orang dewasa, dengan satuannya disebut seta. Ukuran satu seta sama panjangnya dengan jarak dari siku sampai ujung jari tengah. Ukuran ini sering digunakan untuk mengukur tinggi Takin.

\section{Mendesain}

Pendesainan merupakan salah satu aktivitas yang berkaitan dengan mate-matika terapan. Aktivitas pendesainan yang dilakukan masyarakat berkaitan dengan kegiatan membuat rancang bangun telah diterapkan oleh semua jenis suku dan budaya. Rancang bangun bukan hanya monopoli dari aktivitas-aktivitas produk-produk pabrikan, tetapi juga sering dilakukan oleh masyarakat dalam berbagai kegi-atan seperti mendirikan rumah tempat tinggal termasuk aktivitas yang telah dilakukan masyarakat yang lalu dalam membangun rumah panjang - betang , perdagangan, alat-alat pertanian, perdagangan, peperangan, permainan, perhiasan, kerajinan mau-pun alat-alat kebutuhan rumah tangga.

Kegiatan merancang bangun masyarakat dapat dilihat pada saat mereka mem-buat perencanaan dan pada saat pelaksanaannya. Konsep matematika yang terkait pada rancang bangun ini adalah konsep membilang, 
konsep simetri, konsep keindah-an dan ketepatan ukuran. Hitung-menghitung berkaitan dengan kebutuhan bahanbahan pembuatan bangunan seperti menghitung banyak tiang, kasau reng, pintu, atap, papan dinding, papan lantai dsb. Salah satu aktivitas unik masya-rakat untuk menentukan supaya bangunan "siku" dilakukan dengan menggunakan konsep segitiga sikusiku Pythagoras yang tidak diketahui dan disadari oleh pelakunya.

Kegiatan pendesainan lain yang banyak dilakukan oleh masyarakat suku Dayak adalah ketika mereka membuat produk budaya, seperti : membuat anyaman tikar dengan menggunakan berbagai bahan baku, nyiru (tampah atau nampah), menenun kain dan membuat perisai. Pada proses pembuatan perisai aktivitas men-desain dilakukan pada saat membentuk motif pada perisai tersebut. Motif perisai dibuat pada salah satu sisi perisai dan kemudian untuk menggambar atau mengukir motif pada sisi yang lainnya berpatokan motif belahannya.

\section{Penentuan lokasi atau letak}

Dalam kehidupan sehari-hari masyarakat Dayak banyak ditemukan aktivitas mereka yang menyimpan konsep-konsep geometri penentuan suatu lokasi. Masya-rakat Dayak sebagian besar warganya hidup dan mencari penghidupan dengan menggantungkan diri kepada hutan-hutan di sekitar lingkungannya, baik itu kegiatan berburu binatang, mencari dan membuka lahan baru untuk bertani atau berladang, mencari buah-buahan hutan, madu, rotan dan sebagainya. Tidak ada rasa takut tersesat dalam diri masyarakat untuk keluar masuk hutan rimba. Sejauh manapun memasuki wilayah asing atau hutan, mereka selalu dapat menemukan arah kembali pulang ke rumahnya atau posisi awal. Dalam hal ini, masyarakat telah menerapkan konsep navigasi yang bermanfaat untuk menuntun mereka menemukan arah perjalanan yang tepat. Masyarakat Dayak telah mengembangkan teknik pengkodean atau pemberian simbol dengan makna tertentu yang diberlakukan di lingkungannya. Selain itu aktivitas penentuan lokasi atau letak yang juga dilakukan oleh masyarakat Dayak adalah aktivitas dalam meletakkan suatu motif di tempat yang semestinya. Aktivitas ini berkaitan erat dengan konsep simetri dan jarak dua benda dalam bidang. Apabila seorang pengrajin hendak menganyam untuk membentuk suatu motif, maka di tahap awal anyamannya si pengrajin tersebut memulai dengan anyam tunggal. Anyam tunggal adalah anyaman dengan aturan satu lembar lusi (iratan bilah bambu arah melintang) ditimpa dengan satu lembar pakan (iratan bilah bambu arah membujur) kemudian dilanjutkan dengan anyam dua (berbentuk garis). Anyam dua adalah anyaman dengan aturan dua lembar lusi (iratan bilah bambu arah melintang) ditimpa oleh dua lembar pakan (bilah bambu yang membujur). Pada seni kerajinan ini, pembentukan motif dilakukan setelah anyam dua selesai dikerjakan.

Penentuan letak untuk suatu motif berikutnya, dilakukan oleh si penganyam bila motif perdana dan motif bentuk simetrisnya telah selesai dibuat, maka motif tersebut dianggap selesai. Pembentukan motif berikutnya dilakukan dengan pengu-langan pada aturan sebelumnya. Namun, apabila bentuk hasil anyaman suatu motif dengan bentuk simetrinya tidak sama 
ukuran maka dipastikan terjadi kesalahan peletakan motif ataupun terjadi kesalahan dalam hitungan aturan anyaman sehingga menyebabkan perbedaan ukuran motif.

\section{Menjelaskan}

Menjelaskan berkaitan dengan proses menceritakan makna dan filosopi setiap motif dari generasi ke generasi sehingga pesan-pesan moral terus disampaikan dan tidak hilang. Aktivitas menjelaskan makna motif oleh para penganyam dilakukan bila proses penganyaman sudah selesai dan menghasilkan produk anyaman yang diinginkan.

Ada keyakinan dalam diri para penganyam bahwa aktivitas menganyam tidak boleh dilakukan bersamaan dengan aktivitas menceritakan hal ikhwal motif yang terkandung dalam anyaman. Apabila hal itu dilanggar mereka takut anyamannya tidak kunjung selesai bahkan ada ketakutan akan ditimpa suatu penyakit.

\section{Ragam Motif Produk Kerajinan Masyarakat Dayak}

Salah satu bentuk identitas dari suku Dayak adalah ukirannya yang khas dan unik. Bagi sebagian suku Dayak, patung dan beberapa benda seni yang menjadi kekhasan suku memiliki pesan dan makna yang perlu diungkap. Selain patung, ada juga karya budaya yang lainnya seperti anyaman dengan berbagai bahan baku, dari bamboo, rotan, keladi air, sampai enceng gondok yang memiliki pola-pola atau motif-motif unik pada produkproduknya. Pola yang disenangi umumnya dari bentuk-bentuk alam seperti tumbuhan, binatang serta roh dari dewa-dewa, misalnya Naang
Brang, Pen Lih, Deing Wung Loh, dan sebagainya.

Etnomatematika yang digunakan masyarakat Dayak, selain tersembunyi di dalam aktivitas juga terdapat pada berbagai motif yang digunakan untuk memberi pemanis pada produk-produk kerajinan anyaman. Salah satu produk kerajinan masyarakat Dayak adalah anyaman dengan bahan baku dari bamboo.

Berdasarkan hasil penggalian informasi dari para informan dalam kriya anyaman dapat diinventarisir ada sebanyak dua belas motif yang dikembangkan oleh masyarakat untuk mempercantik produknya. Ke-dua belas motif itu termuat pada produk anyaman baik berupa topi, tikar, juah, jongkuak, atau bakul adalah : siluk langit, ati lang, sulau, siku remaung, berangan lang, bunga tekembai, angkong, bulan, pangkak, tambat manuk, kiarak nyulur, lekuk sawak.

Motif Siluk Langit yang terdapat anyaman tikar berbentuk bidang segi dela-pan beraturan. Rancangan motif ini diinspirasi dari pelamunan ketika menatap langit yang begitu luas dan tinggi. Makna pembelajaran dari motif ini mengingatkan kepada manusia agar tidak sombong atas kepandaian maupun kekayaan yang dimiliki karena di atas kehebatan manusia masih ada langit yang kedudukan tetap lebih tinggi.

Motif Ati Lang yang termuat pada anyaman tikar berbentuk bidang belah ketupat. Rancangan pembentukan motif Ati Lang diilhami keperkasaan burung Elang yang mempunyai sikap tekun dalam mengintai mangsanya dari udara, pengintaian tidak berhenti sehingga ia mendapat kesempatan untuk menyambar mangsanya. Motif ini 
memberi pesan pelajaran agar tidak mudah menyerah untuk menghadapi segala kesulitan hidup dan tetap tegar.

Motif Sulau terdapat pada anyaman tikar sebagai alas untuk menaruh per-lengkapan sesaji dan topi petani berbentuk lingkaran. Sebagaimana fungsinya Motif sulau ini sering dijumpai pada tikar untuk menaruh sesaji. Melambangkan kehidupan orang-orang yang dianggap suci, dihormati, meskipun telah meninggal tetap dikenang karena pengaruh hidupnya yang dirasakan semua orang membawa perubahan kearah yang lebih baik. Makna Sulau menunjukkan ketulusan dan kesucian/keterbukaan dalam menerima setiap perbedaan yang ada, baik masalah sosial maupun keagamaan dan manusia bertanggung jawab dalam penciptaan perdamaian di antara sesamanya.

Berangan Lang adalah motif yang terdapat anyaman topi, tikar sesaji, dan juah atau bakul di rancang dalam bentuk laying-layang. Rancangan motif ini diinspirasi dari buah Berangan Lang, meskipun buah ini berduri namun tetap dibutuhkan. Perlu usaha dengan menaruh sikap berhati-hati agar tidak tertusuk duri untuk bisa menik-mati kelezatan buahnya karena seluruh permukaan kulitnya tertutup duri. Motif ini mengajarkan kepada manusia bahwa untuk mendapatkan sesuatu yang baik enak tidak selalu tersedia dengan sendirinya, tetapi biasanya memerlukan usaha keras, berhati-hati, penuh pertimbangan dan seringkali memerlukan pengorbanan.

Motif Bunga Tekembai yang terdapat pada anyaman topi berbentuk persegi. Bunga yang tumbuh mekar menandai akan dimulainya musim buah-buahan yang bagi masyarakat Suku Dayak. Pertumbuhan bunga merupakan sesuatu yang menggembirakan karena kehidupan masyarakat banyak tergantung kepada kemurahan alam. Manusia diingatkan untuk saling berbagi - saling memberi, baik terhadap sesama maupun terhadap alam.

Motif Angkong yang berbentuk Segitiga sama sisi terdapat pada anyaman topi petani. Motif ini merupakan motif yang dijadikan pelajaran pertama bagi seorang ingin belajar menganyam (ada kepercayaan bahwa untuk penganyam pemula harus memulai belajar menganyam dengan motif ini dan jika dilewati akan mengakibatkan jatuh sakit). Motif ini mengajarkan bahwa segala sesuatu harus dimulai dari awal dan dipelajari secara bertahap sedikit demi sedikit.

Bulan merupakan salah satu motif yang berbentuk Segi delapan beraturan dan dianyam pada topi dan tikar sesaji. Motif ini sebagai ungkapan kekaguman masya-rakat Dayak terhadap keindahan - kelembutan rembulan. Sinar rembulan yang lembut dan bentuknya saat bulan purnama yang indah melambangkan manusia atau sesuatu yang begitu dihargai, dihormati ataupun disukai oleh setiap orang karena sifatnya yang menyenangkan dan kehadiran selalu memberi manfaat kepada orang lain.

Motif pangkak yang dibuat dalam dimensi dua terdapat pada anyaman topi. Seperti Pangkak yang terus berputar selagi ia mampu berputar, demikian juga hendaknya perputaran pangkak dijadikan pelajaran bagi setiap manusia untuk terus belajar hingga akhir hayat. 


\section{Simpulan}

Hasil penelitian menunjukkan bahwa dalam menjalani kehidupan sehari-hari maupun dalam pelaksanaan adat istiadat dan upacara, masyarakat subsuku Dayak yang tinggal di wilayah perbatasan Indonesia-Malaysia memiliki tata cara sendiri, yang unik dan khas lokal mereka Perlengkapan-perlengkapan yang diperlukan dalam pelaksanaan upacara adat dan ritual meliputi berbagai jenis, dan masing-masing ditetapkan dalam jumlah tertentu. Itu menunjukkan bahwa di dalam aktivitas adat secara tidak sadar mereka menerapkan pengetahuan matematika ala masyarakat setempat dengan memberikan batasan sesuai kesepakatan mereka. Bagi masyarakat Dayak, ritus merupakan ekspresi, atau ungkapan sikap "hamba" kepada Yang Transenden dan ritual menujukkan formalisasi perilaku manusia ketika berhadapan dengan objek yang suci.

Etnomatematika dalam tingkatan sederhana banyak digunakan oleh masya-rakat Dayak dalam menjalani kehidupan seharihari. Konsep yang sering digunakan adalah konsep berhitung, membilang, mengukur, menimbang, menentukan lokasi, merancang, membuat bangunbangun simetri. Aktivitas masyarakat yang bermuatan etnomatematika ini dapat dikembangkan sebagai sumber belajar matematika sekolah yang kontekstual - realistik.

Aktivitas sebagian masyarakat subsuku Dayak dalam memproduksi anyam-an, khususnya anyaman topipetani yang disulam berbagai motif, memuat sejumlah konsep advance elementary geometry. Etnomatematika yang digunakan masyarakat ini berpotensi untuk dikembangkan menjadi bahan pembelajaran mate-matika. Konsepkonsep dimaksud meliputi konsep geometri dimensi-3 dan dimensi-2. Konsep geometri berdimensi-3 yang terkandung dalam anyaman topi adalah kerucut, adapun konsepkonsep berdimensi-2 meliputi : (a) Garis lurus yang terkandung dalam Anyam dua; (b) Garis lengkung yang terkandung dalam motif Lekuk sawak; (c) Kurva tertutup yang terkandung dalam motif Tambat manuk, Kiarak nyulur, Siku remaung, dan Pangkak; (d) Segitiga sama kaki yang terkandung dalam motif Angkong; (e) Persegi yang terkandung dalam motif bunga tekembai; (f) Belah ketupat yang terkandung dalam motif Ati lang; (g) Layang-layang yang terkandung dalam motif Berangan Lang; (h) Simetri; (i) Segi 8 beraturan yang terkandung dalam motif Siluk langit dan Bulan; (j) Lingkaran yang terkandung dalam motif Sulau.

\section{Daftar Pustaka}

Barta, J. \& Shockey, T. (2006). The mathematical ways of an aboriginal people: The Northern Ute. Journal of Mathematics and Culture, 1(1), 79-89.

Banks, J.A. (1994). An Introduction to Multicultural Education. Boston : Allyn \& Bacon.

Bishop, A. J. (1994). Cultural conflicts in mathematics education: developing a research agenda. For the Learning of Mathematics Journal, v14 n2 p15-18. 
Brown, R. (1995). Prejudice: It's Social Psychology. Oxford: Blackwell Publishers

Bryant, N.A. (1996). Make The Curriculum Multicultural. The Science Teacher, 63 (2), 2831.

Hiebert, J. \& Carpenter, T.P. (1992). Learning With Understanding. In Grouws D.A. (ed). Handbook of Research on Mathematics Teaching and Learning, A Project of NCTM. New York : Macmillan.

Lara-Alecio, R (2001). Science of the Maya: Ethnoscience in the Classroom. The Science Teacher, 68 (3), 48-51

Makitan, F. (2009). Study Eksplorasi Konsep Geometri Bangun Datar Dalam Motif Anyaman Bambu Suku Dayak Sekapat, Ketungau Tengah, Sintang. Laporan Penelitian tidak dipublikasikan. Pontianak: FKIP-UNTAN.

Matsumoto, D. (1996). Culture and Psychology. California : Brooks/Cole Publishing Co.

Miles, M.B. \& Huberman, A.M. (1994). Qualitative Data Analysis : An Expanded Sourcebook. $2^{\text {nd }}$ ed. Thousand Oak, CA : Sage.

Pinxten, R. (1994). Ethnomathematics and Its Practice. For the Learning of Mathematics Vol. 14 No. 2.

Santrock, J.W. (1999). Life Span Development, 7th ed. USA : Mc Graw Hill.

Sumarno, U. (2003). Efektifitas Modifikasi Model Kegiatan Praktikum Dari Wheater \& Dunleavy Dalam Pembelajaran Ekologi Hewan.
Tesis PPS UPI: Tidak diterbitkan.

Shirley, L. (2001). Using Ethnomathematics to Find Multicultural Mathematics Conections. In P.A. House \& A.F. Coxford (ed) Connecting Mathematics Across the Curriculum. Reston, VA : NCTM.

Tandililing, E. (2001). Pengembangan

Etnomatematika Dalam Suku Dayak Kanayat'n di Kalimantan Barat (Suatu Upaya Pengembangan Pembelajaran Matematika di Sekolah Dasar. Laporan Penelitian tidak dipublikasikan. Pontianak: FKIP-UNTAN.

van Oers, B. (1996). Learning Mathematics as a Meaningful Activity. In L. P Steffe \& Nesher, P. Proceeding of Theories of Mathematical Learning, $7^{\text {th }} \quad$ International Congress on Mathematical Education. New Jersey : LEA. 
